\title{
Appraisal of the value of selected clays and minerals in diets with and without aflatoxin-contaminated maize fed to young pigs
}

\author{
M.D. Lindemann', D.J. Blodgett, A.F. Harper, E.T. Kornegay \\ and J. A. Doerr
}

Department of Animal and Poultry Sciences, Virginia Polytechnic Institute and State University Blacksburg 2406I, USA

(Received 6 June 1997; accepted 24 October 1997)

\begin{abstract}
Three experiments using 345 crossbred weanling pigs were conducted to further assess the value of different clay and mineral products in situations of aflatoxin contamination and, additionally, in noncontaminated diets. In experiment 1, 54 pigs were used in a 34-d trial to evaluate four amendments added at a rate of $0.5 \%$ to a diet contaminated with $500 \mathrm{ppb}$ aflatoxin. Pigs fed the contaminated diet had reduced ADG of $27.8 \%$; the sodium bentonite amendment resulted in total growth recovery $(\mathrm{P}<0.01)$ and the kaolin amendment resulted in $47 \%$ recovery $(\mathrm{P}<0.05)$ of the growth loss. A special $\mathrm{Mg} / \mathrm{Ca}$ mineral blend resulted in a $60 \%(\mathrm{P}<0.05)$ recovery of the growth loss and maintained feed/gain. A commercial pellet binder provided no amelioration of growth loss. A total of 291 crossbred pigs were used in two experiments, each involving two trials of 28 to $33 \mathrm{~d}$, to assess the response of weanling pigs to amendments evaluated in the first study, plus additional amendments (a zeolite, a calcium bentonite, a saponite, a sepiolite, and another mineral product) in diets that were not contaminated with aflatoxin. Several products enhanced ADG $(P<0.05)$ through improvements in ADFI. No reduction $(\mathrm{P}<0.10)$ in ADG resulted from inclusion of these non-protein- or energy-containing compounds. Results from these studies confirm the utility of clays mitigate the adverse effects of aflatoxin in weanling pig diets and demonstrate occasional enhancement of ADG associated with these amendments in situations when aflatoxin contamination does not occur.
\end{abstract}

KEY WORDS: pigs, aflatoxin, clay, minerals

\footnotetext{
'Corresponding author: Present address Dr. M.D. Lindemann, University of Kentucky, 610 W.P. Garrigus Bldg., Lexington, KY 40546-0215, USA
} 


\section{INTRODUCTION}

Problems of mycotoxin contamination of feedstuffs are routine. The greatest economic losses associated with mycotoxins are not the occasional animal deaths but, rather, the reduced productivity resulting from increased disease incidence and interference with reproductive capacities (CAST, 1989). Recent research (Harvey et al., 1989; Lindemann et al., 1993; Schell et al., 1993b) has demonstrated that certain clays are able to prevent most of the adverse effects associated with ingestion of aflatoxin-contaminated grains. Inclusion of several types of clays in aflatoxin-contaminated diets has enhanced feed intake, restored lost daily gains, and returned clinical chemistry profiles to values similar to those of pigs fed a control diet. Although the value of clays in aflatoxin-contaminated diets is readily apparent, aflatoxin contamination is not a problem at all times; thus the response of pigs to clay additions in situations where contamination is not a problem is of interest. Potentially, clay additions could prove detrimental to feed efficiency because of the simple dilution of the diet with these non-energy-contributing materials. These studies were part of a continuing effort to assess the value of different clay and mineral products in situations of aflatoxin contamination and, additionally, to determine the response of weanling pigs to the inclusion of a variety of clays in noncontaminated diets.

\section{MATERIAL AND METHODS}

\section{Amendments to aflatoxin-contaminated diets}

Experiment 1. A group of pigs was weaned at a mean age of $27.2 \mathrm{~d}$ and allowed a 7-d adjustment period prior to study initiation. Pigs were reweighed and a subgroup of 54 pigs ( 42 barrows and 12 gilts) was selected and blocked on genetic background, gender, body weight, and performance during the adjustment period. Pigs were then randomly allotted from within block to pens and the six dietary treatments randomly assigned to the $0.98 \mathrm{~m} \times 1.31 \mathrm{~m}$ pens. There were three replicate pens of three pigs each per dietary treatment. The mean initial age and weight of pigs when the dietary treatments were started was $34.2 \mathrm{~d}$ and 9.21 $\mathrm{kg}$, respectively.

Pigs were housed in an environmentally controlled nursery and allowed ad libitum access to water and feed (basal diet composition is described in Table 1). Temperature and ventilation rates were adjusted on the weekly weigh dates according to the body weights of the smallest pigs.

The six dietary treatments consisted of noncontaminated and contaminated control diets and contaminated diets amended with one of four products at the 
TABLE 1

Percentage composition of basal diets used in the studies ${ }^{\mathrm{a}}$

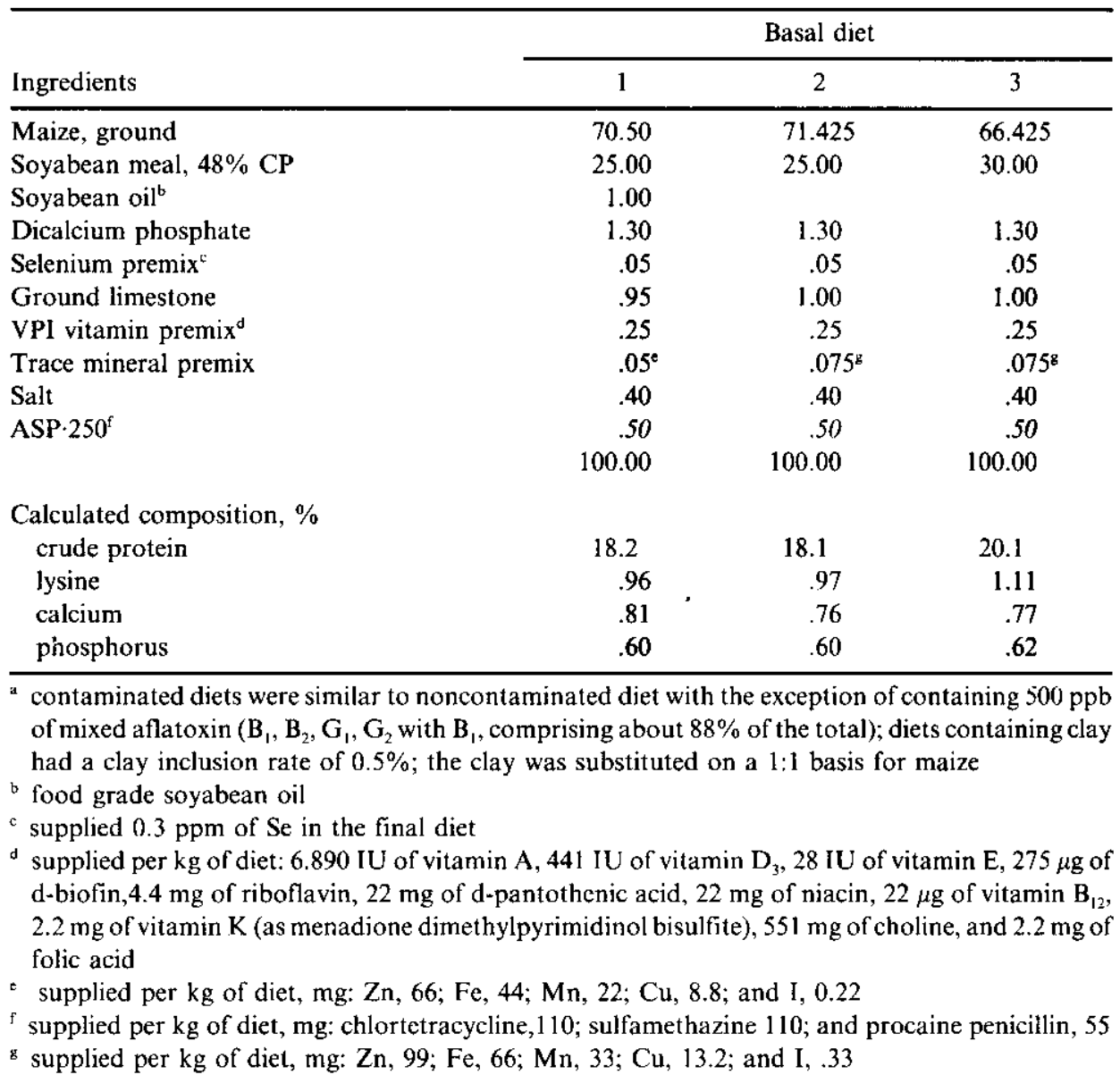

rate of $0.5 \%$. Contaminated diets ( $500 \mathrm{ppb}$ of aflatoxin $\mathrm{B}_{1}$ ) were prepared using rice starch contaminated using the procedure of Shotwell et al. (1966) with the modifications of West et al. (1973) and Wiseman et al. (1970). Two clay treatments, constituted two of the four amendments. The first clay was a product called FD-181 (a sodium bentonite obtained from American Colloid Co., Arlington Heights, IL) that has demonstrated utility in alleviating some of the adverse effects of aflatoxin-contaminated diets; it was included as a control to verify that the pigs were responding as they routinely had in previous trials. The second clay was a kaolin (obtained from Iowa Limestone Co., Des Moines IA); previously, kaolin added to aflatoxin-contaminated poultry diets has not been of 
benefit in preventing aflatoxicosis (Wyatt, R. D., personal communication), although it has demonstrated ability to adsorb aflatoxin in vitro (Maryamma et al., 1991). Two mineral products were evaluated (from Martin Marietta Magnesia Specialties Inc., Hunt Valley, MD); one was a commercial pellet binder (PeIPlus 200), whereas the other was a special Mg/Ca blend. At the end of the trial (34 d post-trial initiation), a blood sample was obtained from the anterior vena cava of each pig. Clinical chemistry profile analyses were obtained on the serum through the Virginia/Maryland Regional College of Veterinary Medicine using a Kodak Ektachem 700 Analyzer (Eastman Kodak Rochester, NY).

\section{Amendments to noncontaminated diets}

Experiment 2. A total of 125 crossbred weanling pigs were utilized in two 4-wk trials to assess response to dietary additions of various clays in diets that were not contaminated with aflatoxin. Trial 1 utilized 70 pigs with a mean initial age and weight of $27.9 \mathrm{~d}$ and $7.62 \mathrm{~kg}$, respectively. Trial 2 utilized 55 pigs with a mean initial age and weight of $26.1 \mathrm{~d}$ and $7.30 \mathrm{~kg}$, respectively. Immediately after weaning, the pigs were randomly assigned from outcome groups based on litter, gender, and body weight to one of the following five treatments: 1 . control diet with no amendment, $2-5$ control diet with $0.5 \%$ of an amendment. The control diet was a maize-soyabean meal based diet that contained $18.1 \%$ crude protein $(0.97 \%$ lysine $)$ and was fortified with vitamins and minerals to meet or exceed NRC (1979) requirement estimates (basal diet number 2; Table 1). The four clays evaluated were: 1 . a sodium bentonite, trade name FD-181,2 a zeolite with traces of montmorillonite clay, trade name Zeobrite, obtained through Iowa Limestone Co., Des Moines, IA, 3. a treated calcium bentonite, trade name AB-20, obtained through Prince Agri Products Inc., Quincy, IL and 4. an attapulgite, trade name 55-RVM, obtained from Floridin Co., Tallahassee, FL. All four of these clays had previously effected various degrees of improvement in growth performance when included in diets contaminated with about $800 \mathrm{ppb}$ aflatoxin $\mathrm{B}_{1}$, (Lindemann et al., 1993; Schell et al., 1993b). Trials 1 and 2 involved 4 and 3 replicate pens of pigs per treatment, respectively. Three or four pigs were housed per $0.98 \mathrm{~m} \times 1.31 \mathrm{~m}$ pen in an environmentally-regulated nursery and allowed ad libitum access to feed and water. Pig body weights and feed weighbacks were obtained weekly.

Experiment 3. A total of 166 crossbred weanling pigs were utilized in two trials to assess the response of pigs to dietary additions of various amendments in diets that were not contaminated with aflatoxin. Trial 1 utilized 78 crossbred pigs in a 33-d trial. The pigs were weaned at a mean age of $25.1 \mathrm{~d}$ and started the trial at 
a mean weight of $7.09 \mathrm{~kg}$. The pigs were randomly assigned from outcome groups based on litter, gender, and body weight to one of the following six treatments: 1. a control maize-soyabean meal based diet that contained $18.1 \%$ crude protein $(0.97 \%$ lysine $)$ and was fortified with vitamins and minerals to meet or exceed NRC (1979) requirement estimates (basal diet number 2; Table 1) $2-6$ control diets amended with various clay or mineral products at the rate of $0.5 \%$; the products were added at the expense of maize when utilized. The products evaluated were: 1 . a sodium bentonite, trade name Volclay-90, obtained from American Colloid Co., Arlington Heights, IL; 2. a pellet binder, trade name PeIPlus; 3. a special $\mathrm{Mg} / \mathrm{Ca}$ blended mineral product; 4 . na saponite clay, trade name Imvite 1016, obtained from Floridin Co., Tallahassee, FL; and 5. a sepiolite clay, trade name IGS, obtained from Floridin Co., Tallahassee, FL. The pigs were penned 3 or 4 per $0.98 \mathrm{~m} \mathrm{x} 1.31 \mathrm{~m}$ pen in an environmentallycontrolled nursery and allowed ad libitum access to water and feed. A total of four replications of the dietary treatments were utilized. Temperature and ventilation rates were adjusted weekly according to the body weights of the smallest pigs.

A total of 88 pigs were utilized in Trial 2 which was $28 \mathrm{~d}$ in length. The pigs were weaned at a mean age and weight of $29.9 \mathrm{~d}$ and $8.21, \mathrm{~kg}$ respectively. The pigs were randomly assigned from outcome groups based on litter, gender, and body weight to one of the following six dietary treatments: 1 . a control maize-soyabean meal based diet that contained $20.1 \%$ crude protein $(1.11 \%$ lysine) and was fortified with vitamins and minerals to meet or exceed NRC (1979) requirement estimates (basal diet number 3; Table 1), and 2-6 the control diet amended with various clay or mineral products at the rate of $0.5 \%$ the products were added at the expense of maize when utilized. The products evaluated were: 1. a mineral product from the western U.S., trade name Azomite, obtained through Prince Agri Products Inc., Quincy, IL; 2. a pellet binder, trade name Pel-Plus; 3. a special $\mathrm{Mg} / \mathrm{Ca}$ blended mineral product; 4 . a saponite clay, trade name Imvite 1016; and 5. a sepiolite clay, trade name IGS. A total of four replicate pens (four pigs per $0.98 \mathrm{~m} \times 1.31 \mathrm{~m}$ pen) were utilized for all products except the Pel-Plus and IGS products of which a limited supply of material restricted the number of replicates to three. Temperature and ventilation rates were adjusted on the weekly weighdays according to the body weights of the smallest pigs. The pens were in an environmentally-controlled nursery and pigs were allowed ad libitum access to water and feed.

For all studies, the floor space allowances, care of the pigs, and ambient temperatures were consistent with the recommendations suggested in the Guide for the Care and Use of Agricultural Animals in Research and Teaching (Consortium, 1988). 


\section{Statistical analysis}

The data for all trials were subjected to an analysis of variance utilizing the GLM procedure of SAS (1990). Pen means were utilized for comparisons relative to average daily gain (ADG), average daily feed intake (ADFI), feed/gain and serum chemistry values. When the studies involved contaminated diets, single degree-of-freedom comparisons were made between each dietary amendment and the unamended aflatoxin-contaminated diet. In studies that did not have contaminated diets, the single degree-of-freedom comparisons were made between each dietary amendment and the unamended control diet. When data from multiple trials were combined for analysis, homogeneity of variance was tested by Hartley's $f_{\max }$ test as presented by Gill (1978) to assure that combining the trials was valid.

\section{RESULTS AND DISCUSSION}

\section{Amendments to aflatoxin-contaminated diets}

Growth performance of the pigs during the trial period was as anticipated with a $27.8 \%$ reduction in growth rate at trial termination (Table $2 ; 0.355 / 0.490$ $\mathrm{kg}$ ) because of the aflatoxin in the diet. The growth reduction was $14.6 \%$ after two weeks and increased as the trial progressed. It should also be noted that the inclusion of the product FD-181 resulted in total recovery of the growth rate depression associated with the aflatoxin inclusion. Based on the observed decline in growth rate by pigs fed the contaminated diet and the restoration of performance by the clay which had previously demonstrated effectiveness, we can conclude that the research model was functioning normally. This is the first trial conducted at this station in which total recovery of growth performance was observed from any dietary amendment tested. In many of the earlier trials (Lindemann et al., 1993; Schell et al., 1993b), the reductions in growth rate have been associated exclusively with alterations in daily feed intake with no effects noted on feed/gain. In this trial there were no significant differences noted at any time point for daily feed intake among the two control diets and the supplemented with FD-181; hence, there were improvements $(\mathrm{P}<0.05)$ in diet feed/gain when the pigs were fed the uncontaminated diet or the contaminated diet with the FD-181. This should not necessarily be viewed as improvements in biological utilization of feed. One phenomenon that sometimes occurs with contaminated diets (and which was observed in this trial) is that the pigs fed the contaminated diet will root in the feeder as if looking for better feed and in the process there is more feed waste. The elevation, then, in feed/gain of the pigs fed 
TABLE 2

Performance of pigs fed aflatoxin-contaminated diets with various amendments ${ }^{\mathrm{a}}$

\begin{tabular}{|c|c|c|c|c|c|c|c|}
\hline \multirow{3}{*}{$\begin{array}{l}\text { Aflatoxin, ppb } \\
\text { Amendment }^{\mathrm{b}}\end{array}$} & \multicolumn{7}{|c|}{ Dietary treatments } \\
\hline & 0 & 500 & 500 & 500 & 500 & 500 & SEM \\
\hline & - & - & 1 & 2 & 3 & 4 & \\
\hline \multicolumn{8}{|l|}{ Body weight, kg } \\
\hline initial & 9.17 & 9.24 & 9.19 & 9.23 & 9.24 & 9.18 & .041 \\
\hline week 2 & 12.64 & 12.25 & 13.32 & 12.73 & 13.02 & 12.26 & .404 \\
\hline week 4 & $21.96^{* *}$ & 19.01 & $21.93^{* *}$ & 19.93 & $20.65^{*}$ & 19.13 & .495 \\
\hline final & $25.79^{* *}$ & 21.31 & $25.78^{* *}$ & 23.47 & $24.02^{*}$ & 21.17 & .706 \\
\hline \multicolumn{8}{|l|}{$\mathrm{ADG}, \mathrm{kg}$} \\
\hline 0-2 week & .249 & .213 & .295 & .249 & .268 & .218 & .0284 \\
\hline $0-4$ week & $.458^{* *}$ & .349 & $.454^{* *}$ & .381 & $.408^{*}$ & .354 & .0173 \\
\hline total trial & $.490^{* *}$ & .355 & $.488^{* *}$ & $.419^{*}$ & $.435^{*}$ & .353 & .0206 \\
\hline \multicolumn{8}{|l|}{ ADFI, kg } \\
\hline $0-2$ week & .508 & .572 & .585 & .513 & .503 & .531 & .0428 \\
\hline 0-4 week & .848 & .830 & .894 & .758 & .758 & .762 & .0509 \\
\hline total trial & .947 & .891 & .975 & .848 & .845 & .811 & .0508 \\
\hline \multicolumn{8}{|l|}{ Feed/Gain } \\
\hline $0-2$ week & 2.04 & 2.71 & 2.00 & 2.11 & 1.89 & 2.48 & .2783 \\
\hline $0-4$ week & $1.85^{*}$ & 2.37 & 1.97 & 1.99 & $1.87^{*}$ & 2.14 & .1352 \\
\hline total trial & $1.94^{*}$ & 2.50 & $2.00^{*}$ & 2.03 & $1.94^{*}$ & 2.32 & .1577 \\
\hline \multicolumn{8}{|c|}{$\begin{array}{l}\text { a total of } 54 \text { pigs, } 42 \text { barrows and } 12 \text { gilts, were utilized in a } 34-\mathrm{d} \text { study with three replicates of three } \\
\text { pigs/pen; ADG }=\text { average daily gain, ADFI }=\text { average daily feed intake; statistical significance of } \\
\text { the difference of a treatment mean to that of the } 36 \text { unamended, contaminated diet (data column } 2 \text { ) } \\
\text { is denoted bv: } * \mathrm{P}<0.05 ; * * \mathrm{P}<0.01\end{array}$} \\
\hline
\end{tabular}

the contaminated diet can be, to a degree, due to feed waste. In the sense, and to the extent, that the search for better feed may be due to palatability problems or some behavioural modifications in feed searching, the feed/gain differences could be considered biological, but not necessarily with regard to actual nutrient utilization.

The kaolin clay did provide some amelioration of the negative effects of the contaminated diet. This differs from the response in poultry where kaolin as not demonstrated efficacy in aflatoxin-contaminated diets (Wyatt R.D., personal communication) and suggests either potential clay/species specificity or variability of kaolins in affecting aflatoxin adsorption. With regard to the mineral products, the PeIPlus 200 product provided no amelioration of lost growth rate at any time point assessed. Conversely, the special $\mathrm{Mg} / \mathrm{Ca}$ blend provided 
numerical improvements in growth rate at all time points, being significant $(\mathrm{P}<0.05)$ at 4 weeks and at the trial termination. The special blend also provided the most uniform improvements in feed/gain of any of the products tested being improved at each time point $(\mathrm{P}<0.10$ to 0.05$)$ and, actually, being numerically identical to the uncontaminated diet at trial termination.

The results of the clinical chemistry profile are detailed in Table 3 . Blood urea nitrogen (BUN), total protein and albumin are indicators of nitrogen utilization and protein synthetic capabilities, which are typically depressed in situations of aflatoxicosis. That depression is evident comparing the uncontaminated diet with the contaminated, unamended diet. Aflatoxicosis also often results in elevations of the enzymes aspartate aminotransferase (AST), alkaline phosphatase (ALKP) and gamma glutamyl transferase (GGT). This serum enzyme elevation is indicative of either damage to hepatocytes and leakage of these enzymes into the blood or cholestasis. Liver damage/dysfunction is evidence by the elevation of GG $(P<0.01)$ in this trial; AST and ALKP were not appreciably elevated in this trial, though tlne change in the values was in the direction that would typically be observed. In trials conducted at this station there has been

TABLE 3

Clinical chemistry of pigs fed aflatoxin-contaminated diets with various amendments ${ }^{\mathrm{a}}$

\begin{tabular}{lccccccc}
\hline & \multicolumn{7}{c}{ Dietary treatments } \\
\cline { 2 - 8 } Aflatoxin, ppb & 0 & 500 & 500 & 500 & 500 & 500 & SEM \\
Amendment $^{\mathrm{b}}$ & 1 & 2 & 3 & 4 & & & \\
\hline Blood urea nitrogen, $\mathrm{mg} / \mathrm{dl}$ & 11.7 & 9.7 & 10.7 & $11.8^{*}$ & 11.1 & 10.6 & .69 \\
Total protein, g/dl & 6.2 & 6.1 & 6.2 & 5.9 & 5.9 & 5.9 & .12 \\
Albumin, g/dl & 3.8 & 3.5 & $3.9^{*}$ & 3.6 & 3.6 & 3.6 & .12 \\
AST $^{\mathrm{c}}, \mathrm{U} / \mathrm{I}$ & 70 & 91 & 87 & 77 & 75 & 78 & 11.4 \\
ALKP $^{\mathrm{c}}, \mathrm{U} / \mathrm{I}$ & 214 & 228 & 218 & 200 & 228 & 235 & 11.6 \\
GGT $^{\mathrm{c}}, \mathrm{U} / \mathrm{I}$ & $31^{* *}$ & 46 & 37 & $33^{*}$ & 38 & 51 & 3.0 \\
Sodium, mmol/I $_{\text {Potassium, mmol/I }}$ & 146 & 144 & 146 & 144 & 143 & 141 & 1.2 \\
Chloride, mmol/I & 6.0 & 5.6 & 5.9 & 5.6 & 5.6 & 5.4 & .15 \\
Calcium, mg/dl & 101 & 100 & 102 & 100 & 98 & 99 & 1.0 \\
Phosphorus, $\mathrm{mg} / \mathrm{dl}$ & 10.8 & 10.5 & 10.9 & 10.8 & 10.8 & 10.5 & .16 \\
\hline
\end{tabular}

${ }^{\text {a }}$ a total of 54 pigs, 42 barrows and 12 gilts, were utilized, with three replicates of three pigs/pen; statistical significance of the difference of a treatment mean to that of the unamended, contaminated diet (column 2 ) is denoted by: ${ }^{*} \mathrm{P}<0.05 ;{ }^{* *} \mathrm{P}<0.01$

b amendment 1 was a sodium bentonite clay (trade name FD-181); amendment 2 was a kaolin; amendment 3 was a special $\mathrm{Mg} / \mathrm{Ca}$ mineral blend; and amendment 4 was a commercially available pellet binder (trade name PelPlus); all amendments were added at the rate of $0.5 \%$

- AST = aspartate aminotransferase; ALKP = alkaline phosphatase and GGT = gamma glutamyl transferase 
little effect on serum electrolytes (sodium, potassium, chloride) or serum macrominerals (calcium, phosphorus) from aflatoxicosis. The values presented here are consistent with that earlier work (Lindemann et al., 1993; Schell et al., $1993 \mathrm{a}, \mathrm{b})$. In this study, there was an effect of aflatoxin on serum potassium $(\mathrm{P}<0.10)$ but all observed values were still within normal physiological ranges (Pond and Houpt, 1978).

\section{Amendments to noncontaminated diets}

Experiment 2. For the total study series, two of the four dietary clay additions (the zeolite and the attapulgite) resulted in improvements $(\mathrm{P}<0.05)$ in ADG of pigs fed those diets (Table 4). Addition of the other two types of clay (the sodium and calcium bentonites) resulted in numerical improvements of $3.7 \%$ which is

TABLE 4

Performance of pigs fed noncontaminated diets with various amendments - experiment $2^{\text {a, b }}$

\begin{tabular}{ccccccc}
\hline Amendment & 0 & FD-181 & Zeobrite & AB-20 & 55 -RVM & SEM \\
\hline $\begin{array}{c}\text { Body weight, kg } \\
\text { Initial }\end{array}$ & & & & & & \\
Trial 1 & 7.61 & 7.63 & 7.66 & 7.67 & 7.57 & .060 \\
Trial 2 & 7.33 & 7.27 & 7.24 & 7.34 & 7.30 & .069 \\
Combined & 7.47 & 7.45 & 7.45 & 7.51 & 7.43 & .046 \\
Final &. & & & & & \\
Trial 1 & 18.90 & 19.67 & 20.48 & 18.83 & 19.18 & .368 \\
Trial 2 & 16.39 & 16.29 & 16.54 & 17.17 & 17.98 & .426 \\
Combined & 17.64 & 17.99 & 18.51 & 18.00 & 18.58 & .282 \\
ADG, kg & & & & & & \\
Trial 1 & .403 & .430 & $.458^{*}$ & .399 & .415 & .0132 \\
Trial 2 & .336 & .334 & .344 & .364 & $.396^{* *}$ & .0152 \\
Combined & .369 & .382 & $.401^{*}$ & .381 & $.405^{*}$ & .0100 \\
ADFI, kg & & & & & & \\
Trial 1 & .874 & .885 & .933 & .865 & .880 & .0184 \\
Trial 2 & .606 & .629 & $.708^{* *}$ & $.714^{* *}$ & $.754^{* *}$ & .0212 \\
Combined & .740 & .757 & .821 & .789 & $.817^{* *}$ & .0141 \\
Feed/Gain & & & & & & .090 \\
Trial 1 & 2.16 & 2.06 & 2.04 & 2.18 & 2.13 & .078 \\
Trial 2 & 1.83 & 1.89 & 2.06 & 1.96 & 1.89 & .090 \\
Combined & 2.00 & 1.98 & 2.05 & 2.07 & 2.01 & .060 \\
\hline
\end{tabular}

${ }^{a}$ trials 1 and 2 involved 4 and 3 replicate pens of pigs per treatment, respectively; ADG =average daily gain, $\mathrm{ADFI}=$ average daily feed intake; statistical significance of the difference of a treatment mean to that of control-fed pigs (column 1) is denoted by: ${ }^{*} \mathrm{P}<0.05 ;{ }^{* *} \mathrm{P}<0.01$

${ }^{b}$ inclusion rate of clays was $0.5 \%$; trials lasted four weeks 
similar in magnitude to that which has been found in nursery pigs in some of our earlier trials (Schell et al., 1993a), but these improvements were not significant $(\mathrm{P}>0.05)$. The improvements in ADG resulted from increases in ADF $(\mathrm{P}<0.01)$ in each instance; no improvement was observed in feed/gain ratio. The inclusion of these clays did not produce any detriment in growth performance in this noncontaminated grain situation.

Experiment 3. In Trial 1, none of the added clays or mineral combinations provided any improvements $(\mathrm{P}<0.05)$ in performance (Table 5). Examination of the diet fed reveals that it contained less lysine than the 1988 National Research Council (NRC) Nutrient Requirements for Swine lists as the requirement estimate for pigs of the bodyweight that started this trial $(0.97 \%$ vs $1.15 \%)$. The lysine levels of this diet did meet the 1979 NRC requirement estimates $(0.95 \%)$ and these same diets were utilized in the earlier study examining clays in noncontaminated diets (Table 4) in which clay effects were noted. So while there may be some question about diet adequacy, the fact that similar diets were utilized in the same facilities in experiments conducted similarly, and that in the previous studies there were effects of clays noted, the diet composition would not seem to be a factor that limited, or prevented, response to the respective treatments.

In Trial 2, the protein/lysine level of the diet was increased slightly (Table 1; basal diet 3). In this trial, the replications were not equal for all products because of a limited amount of product available at the time of mixing. Because of the effect that this unequal replication has on the F-statistic and the resultant P-value for the difference between means, there is an apparent oddity in that some means are noted as differing from the control value whereas other means of greater difference do not have statistical notations of difference.

With regard to ADG, the only means which differed were with the Azomite product which exhibited improved growth rate $(14.5 \% ; \mathrm{P}<0.05)$ for the total trial. There were no other statistically significant differences but the IGS product did have the numerically greatest ADG response for the trial and the Imvite product also had a $10 \%$ numerical improvement in growth rate. The improvements in growth rate, where observed, were associated principally with alterations in feed intake, because there were no improvements in feed/gain for any amendments.

\section{CONCLUSIONS}

Contamination of diets with a mycotoxin such as aflatoxin occasionally occur irrespective of the quality control standards established for grain 
TABLE 5

Performance of fed noncontaminated diets amended with various mineral or clay additions - experiment $3^{\mathrm{a}, \mathrm{b}}$

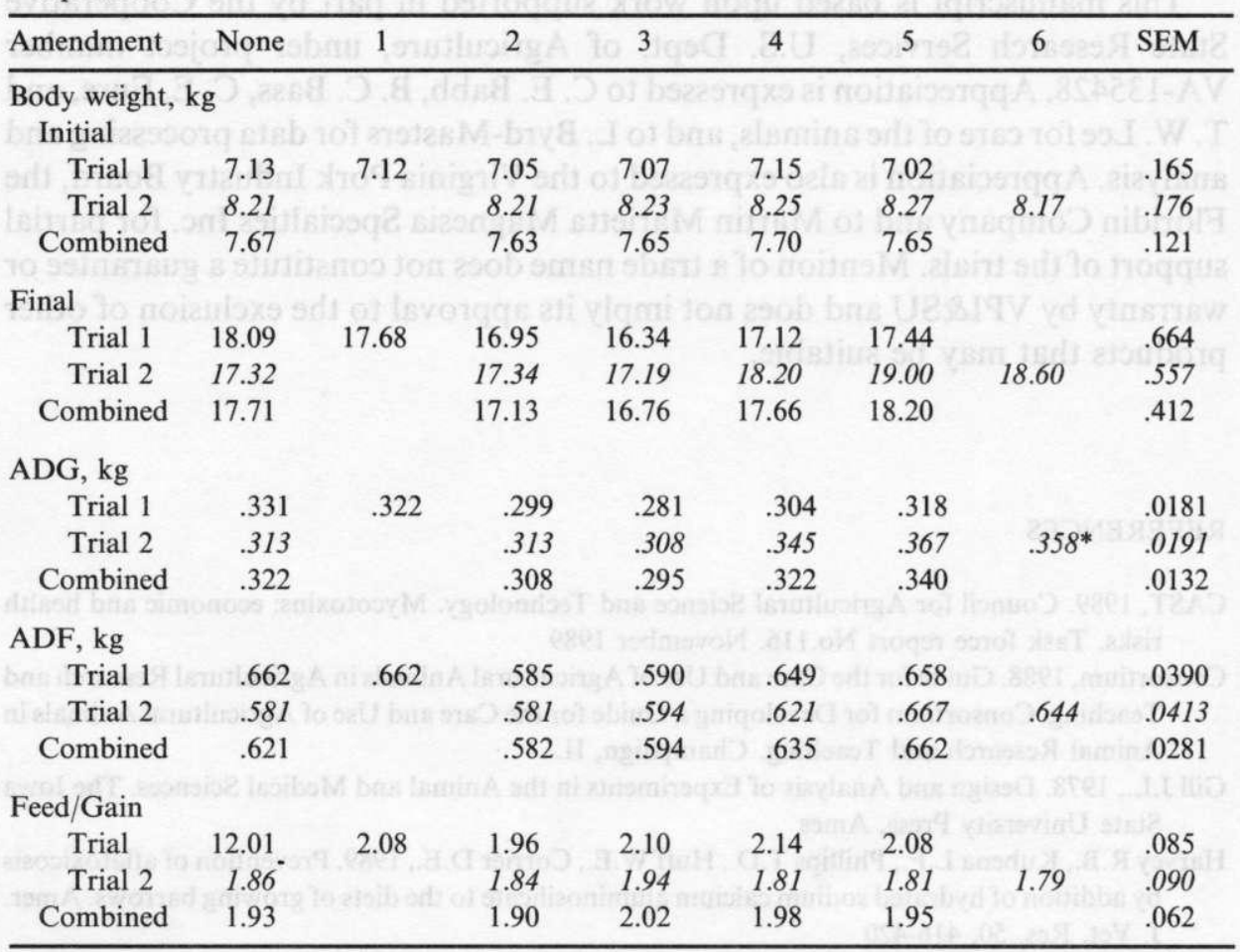

${ }^{\text {a }}$ amenament 1 was a sodium bentonite, trade name Volclay-90; 2 was a pellet binder, trade name PelPlus; 3 was a special I blend; 4 was a saponite clay, trade name Imvite 1016; 5 was a sepiolite clay, trade name IGS; 6 was a mineral product, tra Azomite

${ }^{b} \mathrm{ADG}=$ average daily gain, $\mathrm{ADFI}=$ average daily feed intake; statistical significance of single degree-of-freedom compariso treatment to the control is denoted by, for $* \mathrm{P}<0.05$; four replicate pens used per treatment in bo exception of additives 2 and 5 in Trial 4 which had three replicate pens

purchase. But it occurs more frequently on farms where no grain quality monitoring procedures are practiced. These results affirm the value of low inclusion rates of certain clays or minerals for mitigation of adverse effects associated with aflatoxin ingestion. These results also demonstrate that in situations where contamination does not occur, the response to the amendments is not necessarily negative and frequently is positive for ADG. Therefore, the cost incurred for the products for protection from aflatoxin is not necessarily wasted in situations of noncontamination. 


\section{ACKNOWLEDGEMENTS}

This manuscript is based upon work supported in part by the Cooperative State Research Services, U.S. Dept. of Agriculture, under project number VA-135428. Appreciation is expressed to C. E. Babb, B. C. Bass, C. E. Eure, and T. W. Lee for care of the animals, and to L. Byrd-Masters for data processing and analysis. Appreciation is also expressed to the Virginia Pork Industry Board, the Floridin Company and to Martin Marietta Magnesia Specialties Inc. for partial support of the trials. Mention of a trade name does not constitute a guarantee or warranty by VPI\&SU and does not imply its approval to the exclusion of other products that may be suitable.

\section{REFERENCES}

CAST, 1989. Council for Agricultural Science and Technology. Mycotoxins: economic and health risks. Task force report No.116. Novemter 1989

Consortium, 1988. Guide for the Care and Use of Agricultural Animals in Agricultural Research and Teaching. Consortium for Developing a Guide for the Care and Use of Agricultural Animals in Animal Research and Teaching. Champaign, IL

Gill J.L., 1978. Design and Analysis of Experiments in the Animal and Medical Sciences. The Iowa State University Press, Ames

Harvey R.B., Kubena L.F., Phillips T.D., Huff W.E., Corrier D.E., 1989. Prevention of aflatoxicosis by addition of hydrated sodium calcium aluminosilicate to the diets of growing barrows. Amer. J. Vet. Res. 50, 416-420

Lindemann M.D., Blodgett D.J., Kornegay E.T., Schurig G.G., 1993. Potential ameliorators of aflatoxicosis in weanling/growing swine. J. Anim. Sci. 71, 171-178

Maryamma K.I., Rajan A., Gangadharan B., Manomohan C.B., 1991. In vitro and in vivo studies on aflatoxin B neutralization. Indian J. Anim. Sci. 61, 58-60

NRC, 1979. Nutrient Requirements of Swine. 8th Revised Edition. National Academy Press, Washington, DC

NRC, 1988. Nutrient Requirements of Swine. 9th Revised Edition. National Academy Press, Washington, DC

Pond W.G., Houpt K.A., 1978. The Biology of the Pig. Cornell University Press, Cornell, NY

SAS, 1990. SAS User's Guide: Statistics (Version 6, 4th Edition). SAS Inst. Inc., Cary, NC

Schell T.C., Lindemann M.D., Kornegay E.T., Blodgett D.J., 1993a. Effect of feeding aflatoxincontaminated diets with and without clay on performance,liver function, and mineral metabolism to weanling and growing pigs. J. Anim. Sci. 71, 1209-1218

Schell T.C., Lindemann M.D., Kornegay E.T., Blodgett D.J., Doerr J.A., 1993b. Effectiveness of different types of clay for reducing the detrimental effects of aflatoxin-contaminated diets on performance and serum profiles of weanling pigs. J. Anim. Sci. 71, 1226-1231

Shotwell O.L., Hesseltine C.W., Stubblefield R.D., 1966. Production of aflatoxin on rice. Appl. Microbiol. 15, 425-428

West S., Wyatt R.D., Hamilton P.B., 1973. Improved yield of aflatoxin by incremental increases of temperature. Appl. Microbiol. 25, 1018-1019 
Wiseman H.G., Jacobson W.C., Harmeyer W.C., 1970. Note on the removal of pigments from chloroform extracts of aflatoxin cultures with copper carbonate. J. Assoc. Offic. Agric. Chem. $50,982-983$

\section{STRESZCZENIE}

Określenie wartości preparatów mineralnych dla młodych świń w dietach zawierających kukurydzę porażoną aflatoksyną

Przeprowadzono 3 doświadczenia na 345 odsadzonych prosiętach mieszańcach w celu określenia wartości różnych preparatów mineralnych (bentonit sodowy, kaolin, preparat mineralny PeIPlus 200 i mieszanka wapniowo-magnezowa) dodawanych do diet zawierających kukurydzę porażoną aflatoksyną. W pierwszym 34 dniowym doświadczeniu na 54 świniach oznaczono wpływ czterech dodatków w ilości $0,5 \%$ do diet skażonych $500 \mathrm{ppm}$ aflatoksyny. Prosięta żywione dietą skażoną aflatoksyną miały o $27,8 \%$ obniżone przyrosty masy ciała w odniesieniu do grupy kontrolnej bez dodatku aflatoksyny. Dodatek bentonitu sodowego spowodawał całkowite wyrównanie przyrostów do grupy kontrolnej $(\mathrm{P}<0,01)$, dodatek kaolinu rekompensował obniżkę przyrosów o $47 \%$ $(\mathrm{P}<0,05)$. Podanie mieszanki magnezowo-wapniowej rekompensowało obniżkę przyrostów w $60 \%$, przy zachowanym stosunku spożycia paszy do przyrostu masy ciała.

W dwóch następnych doświadczeniach, każdym skladającym się z dwóch serii 28 i 33 dniowych, przeprowadzonych lącznie na 291 mieszańcach, badano reakcję odsadzonych prosiąt na dodatek do diet nie skażonych aflatoksyną preparatów używanych $w$ doświadczeniu pierwszym, a ponadto zeolitu, bentonitu wapniowego, saponitu, sepiolitu i innych preparatów mineralnych. Kilka preparatów powodowało zwiększenie dziennych przyrostów masy ciała $(\mathrm{P}<0,05)$ dzięki zwiększonemu pobieraniu paszy.

Wyniki tych badań potwierdzają przydatność preparatów mineralnych do zmniejszania niekorzystnego działania aflatoksyn zawartych w dietach dla odsadzonych prosiąt oraz. wskazują na zwiększenie średnich dziennych przyrostów przy dodawaniu niektórych z tych preparatów do diet nie skażonych aflatoksynami. 